что визуальная дисфункция лишь отставляет во времени и замедляет возрастное снижение сложности нейродинамики головного мозга.

Ключевые слова: электроэнцефалография, энтропия Колмогорова-Синая, зрительные дисфункции.

Redka Iryna. Influence of Visiual Dysfunction on Age-rekated Changes of Brain Dynamical Complexity. Progressive increases the data on the non-linear nature of the EEG signal. In this context it is necessary to use new algorithms for the analysis of EEG for better understanding patterns of normal and abnormal brain development. Entropy approach was used in this research to the analysis of the EEG complexity in people from 8 to 20 years with normal vision and congenital visual dysfunction during resting-state with eyes-closed. Age-related reduction of complexity of EEG signal according to the Kolmogorov-Sinai entropy was revealed. This age-related change of complexity was the most significant in teenager males and adolescence females. The age-related entropy reduction was independent of the presence of visual dysfunction. It has been suggested that the visual dysfunction retard to agerelated reduction retards of brain dynamical complexity.

Key words: electroencephalography, entropy Kolmogorov-Sinai, visual dysfunction.

Стаття надійшла до редколегії 15.03.2015 p.

УДК $796.3+796.42$

\title{
Альона Романюк
}

\section{Аналіз латентності Р300 у спортсменів ігрових видів спорту та легкоатлетів}

Виявлено статистичну значиму різницю латентності компоненти Р300 викликаних потенціалів мозку у спортсменів ігрових видів спорту та легкоатлетів. У спортсменів ігрових видів спорту відзначено статистично більший латентний період Р300 порівняно з легкоатлетами під час серії стимулів «Що». Відзначено обернену залежність цих показників між двома групами обстежуваних під час появи стимулів «Де».

Ключові слова: викликані потенціали, компонента Р300, спортсмени, латентний період.

Постановка наукової проблеми та її значення. Сучасне тисячоліття характеризується інтенсивним розвитком наукових досліджень у галузі нейрофізіології, психофізіологіі, медицини, які $\epsilon$ вагомим внеском у розвиток науки загалом. Одним з основних методів аналізу діяльності мозку є вивчення біоелектричних коливань кори головного мозку. Дані, отримані за допомогою цих методів, розкривають суть найважливіших механізмів людського мозку [6, с. 72; 9, с.197].

Викликані потенціали - це реакція, що складається із компонентів, які безперервно пов'язані між собою. Викликані потенціали характеризуються кількісними параметрами окремих компонентів (латентностей та амплітуд). Ці параметри мають різне функціональне значення залежно від особливостей експериментальної моделі. На сьогодні інтенсивно проводяться експериментальні дослідження з пошуку біологічно значимої моделі для прогнозування успішності спортсменів у різних видах спорту, враховуючи не тільки морфологічні, фізіологічні можливості,а також особливості центральної нервової системи[3, с. $113 ; 7$, с. 244].

Спортсмени різних видів спорту володіють певними особливостями нервової системи. Наприклад, основою досягнення високої майстерності, для спортсменів ігрових видів спорту є вміння концентрувати свою увагу, швидко реагувати на зміну ігрової ситуації та приймати рішення [3, с. 113].

Електрофізіологічні методи дослідження дають змогу визначити роль окремих структур головного мозку в процесах уваги і концентрації. Проведення інформації до мозку здійснюється двома шляхами: вентральним, або «Що - системи», який включає вентролатеральнупрестріарну кору та нижньоскроневу кору, та дорзальним, що включає ділянку тім'яної кори, або «Де - система» [1, с. 173; 4, с. 212]. Сказане вище й обумовило актуальність нашого дослідження.

Аналіз досліджень цієї проблеми. Аналіз літературних джерел свідчить, що інтенсивно здійснюються наукові дослідження сомато-сенсорних, слухових, зорових, когнітивних викликаних потенціалів [8, с. 105; 13, с. 11803]. М. Б. Гурова, Л. В. Капилевичвиявили специфічні особливості функ-

(C) Романюк А., 2015 
ціонального стану нервової системи в спортсменів-важкоатлетів та спортсменів-каратистів. У висококваліфікованих спортсменів-каратистів збільшена швидкість аналізу сенсорної інформації порівняно з важкоатлетами [2, с. 195].

Наукові доробки Е. В. Замуліної вагомим внеском у розвиток спортивної психофізіології футболістів. Збільшення амплітуди і зменшення латентного періоду когнітивних викликаних потенціалів P300 засвідчуютьпокращення швидкості протікання процесів переробки інформації у спортсменівфутболістів [3, с. 114].

Методика Р300 широко застосовується для вивчення особливостей мозкових механізмів прийняття рішення, оскільки відображає нейронні процеси, пов'язані із залученням регуляторних ретикулоталамічних систем, лімбічних і неокортикальних структур, що забезпечують спрямовану увагу i короткочасну пам'ять $[11$, с. 782$]$. Наукові результати, отримані експериментальними дослідженнями з викликаних потенціалів, $є$ інформативним критеріємдля відбору спортсменів для того чи іншого виду спорту.

Мета статті - вивчити особливості компоненти Р300 когнітивних викликаних потенціалів у спортсменів ігрових видів спорту та легкоатлетів.

Завдання дослідження:

- проаналізувати латентний період компоненти Р300 викликаних потенціалів у спортсменів ігрових видів;

- дослідити латентність компоненти Р300 у спортсменів легкоатлетів.

Контингент обстежуваних становили спортсмени чоловічої статі, віком 17-21 рік, які мають спортивне звання кандидата у майстри спорту, майстра спорту та III-I розряд. За спортивною спеціалізацією вони були поділені на дві групи: I - спортсмени-легкоатлети, II - спортсмени ігрових видів спорту.

Обстеження здійснювалося за допомогою «НейроКом», розробленого «XАI-Медика». Під час запису електроенцефолограми електроди розміщували за міжнародною системою 10/20 у 19 точках на скальпі голови (Fp1, Fp2 - передньолобові; F3, F4 - задньолобові; F7, F8 - латеральні лобові; Т3, Т4 - передньоскроневі, С3, С4 - центральні; Т5, Т6 - задньоскроневі; Р3, Р4 - тім'яні; О1, О2 потиличні, $\mathrm{Fz}, \mathrm{Cz}, \mathrm{Pz}$ - сагітальні лобові, центральні та тім'янівідведення).

Обстежуваному контингенту на екран монітора подавалися дві серії стимулів - значимих та незначимих. Перша серія «Що» складалась зі 100 стимулів, досліджувані повинні були реагувати на появу зеленого м'яча. Друга серія «Де» - 100 стимулів, обстежувані повинні були реагувати на зелений м'яч лише в тому випадку, якщо він перебував у лівому верхньому куті екрана монітора. Статистичну обробку даних здійснювали за допомогою методів біомедичної статистики 3 використанням статистичної програми MedStat (Ю. С. Лях, В. Г. Гур'янов).

Виклад основного матеріалу й обгрунтування отриманих результатів дослідження. Один із компонентів когнітивних викликаних потенціалів, який ми вивчали, є Р300 - позитивна хвиля, що виникає в інтервалі 250-450 мс після появи стимулу. Вважають, що цей компонент тісно пов'язаний із когнітивними процесами сприйняття та уваги [14, с. 199]. У процесі дослідження латентного періоду Р300 у спортсменів різних видів спорту виявлено статистично значиму різницю позитивної компоненти.

Серія значимих та незначимих стимулів подавалася у вигляді м'ячів, серед яких обстежуваному потрібно було реагувати на появу зеленого м'яча, незалежно від його розміщення на екрані монітора - ця серія отримала назву «Що». Тобто реакція відбувалася на об’єкт і проведення інформації в кору головного мозку здійснювалося за допомогою вентрального шляху.

Спортсмени ігрових видів спорту характеризувалися такими значеннями Р300 - $352 \mathrm{mc} \pm 134,3$ та 290,9 мс \pm 99,63 у легкоатлетіву передньоскроневих відведеннях лівої півкулі кори головного мозку і 386 мс $\pm 100,4$ та 364,9 мс $\pm 125,1$ правої півкулі, при $\mathrm{p}<0,05$. У задньоскроневих відведеннях значення латентності Р300 у групі спортсменів-легкоатлетів були статистично нижчими порівняно з групою спортсменів ігрових видів спорту (рис. 1).

Це вказує на те, що легкоатлети реагують на об'єкт швидше, порівняно зі спортсменами ігрових видів спорту. Очевидно, для досягнення високих результатів у швидкісних видах спорту, тобто під час роботи 3 максимальною потужністю, велику роль відіграє рухливість нервових процесів. На думку багатьох дослідників, рухливість нервової системи в легкоатлетів залежить від довжини дистанції [6, с. 74]. Слід зауважити, що особливістю в легкоатлетів є реакція на «Старт», тобто об'єкт. Отже, скорочення латентності Р300 у нижньоскроневих та задньоскроневих відведеннях у групі спортсменів-легкоатлетів порівняно зі спортсменами ігрових видів спорту свідчать про те, що топографічні особливості 
сприйняття й обробка стимулів, які подавалися досліджуваним, проявляються в чітко визначених зонах кори головного мозку.

Особливе значення в спортивних іграх має швидкість рухових реакцій, яка здебільшого проявляється за рахунок скорочення латентного періоду реакції на подразник. Добре підготовлений спортсмен зводить до мінімуму час на вибір адекватних рухів за рахунок вироблення відповідного динамічного стереотипу. Досвідчений спортсмен миттєво зреагує на будь-які сигнали з боку суперника, що мимоволі видав свої задуми, використовуючи мінімум часу на те, щоб оцінити обстановку й ухвалити рішення [1, с. $173 ; 3$, с. 113$]$.

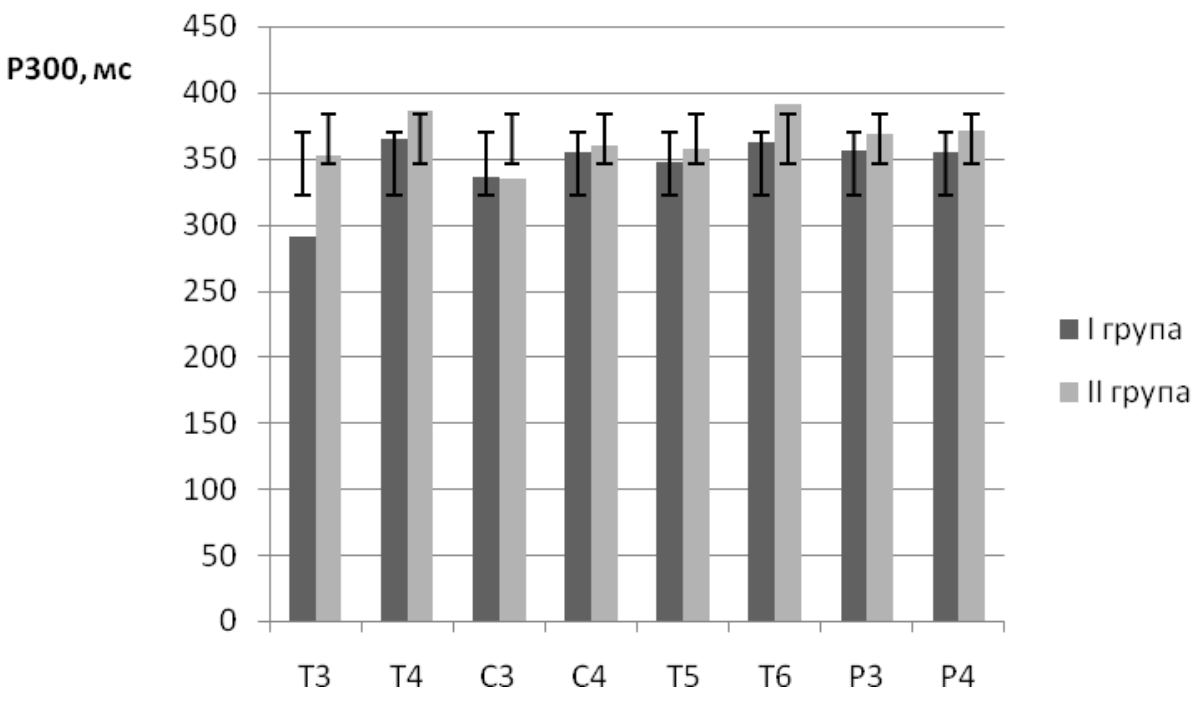

Рис. 1. Латентний період РЗ00 у спортсменів різних видів спорту в серії стимулів «Що»

Тільки достатньо сильна нервова система здатна витримувати велику кількість різних подразників, що поступають від зорового і пропріоцептивного аналізаторів. Сильна нервова система може забезпечувати стійку увагу в поєдинку із суперником у складних ситуаціях, що постійно змінюються. Велике значення в ситуативних видах спорту має врівноваженість нервової системи. Швидкість орієнтування і тактичних висновків забезпечує рухливість нервової системи, тобто здатність своєчасного переходу від збудження або гальмування в одних ділянках кори до таких же процесів - в інших [9, с. 200].

Отримані результати свідчать про те, що спортсмени ігрових видів спорту реагували на об'єкт швидше в серії стимулів «Де». Тобто інформація проводиться за допомогою дорзального потоку, аналіз здійснюється в ділянці тім'яної кори.

На рисунку 2 подано результати латентного періоду Р300 у спортсменів різних видів спорту. Тім'яні відведення кори головного мозку відзначалися статистично нижчими значеннями латентності Р300 у спортсменів ігрових видів спорту порівняно зі спортсменами-легкоатлетами і становили $330,6 \mathrm{mc} \pm 75,26(\mathrm{P} 3)$ та 338,3 мс $\pm 91,05$ (Р4) у групі ігрових видів спорту і $376,6 \mathrm{mc} \pm 70,18(\mathrm{P} 3)$ та $353 \mathrm{мc} \pm 87,07$ у групі легкоатлетів.

Ці результати вказують на те, що група спортсменів ігрових видів спорту потребує швидшої реакції на розміщення об'єкта, тобто здатності швидко реагувати в нестандартній (ігровій) ситуації. Такий прискорений процес переробки інформації в корі головного мозку свідчить про утворення нових тимчасових зв'язків [3, с. 112], унаслідок чого покращується рухова координація у спортсменів ігрових видів спорту порівняно з легкоатлетами.

Аналіз латентності за допомогою методики Р300 дає змогу вивчити особливості мозку в режимі реального часу, розглянути взаємодію його систем у процесі вирішення завдань, виявити здатність розрізняти значиму інформацію від незначимої, швидкість процесів мислення й обсяг оперативної пам'яті. Отже, отримані результати засвідчують те, що психофізіологічні особливості спортсменів різних видів спорту індивідуальні, а обробка та аналіз інформації здійснюється в чітко визначених структурах кори головного мозку, згідно з подвійним потоком інформації до кори головного мозку. 


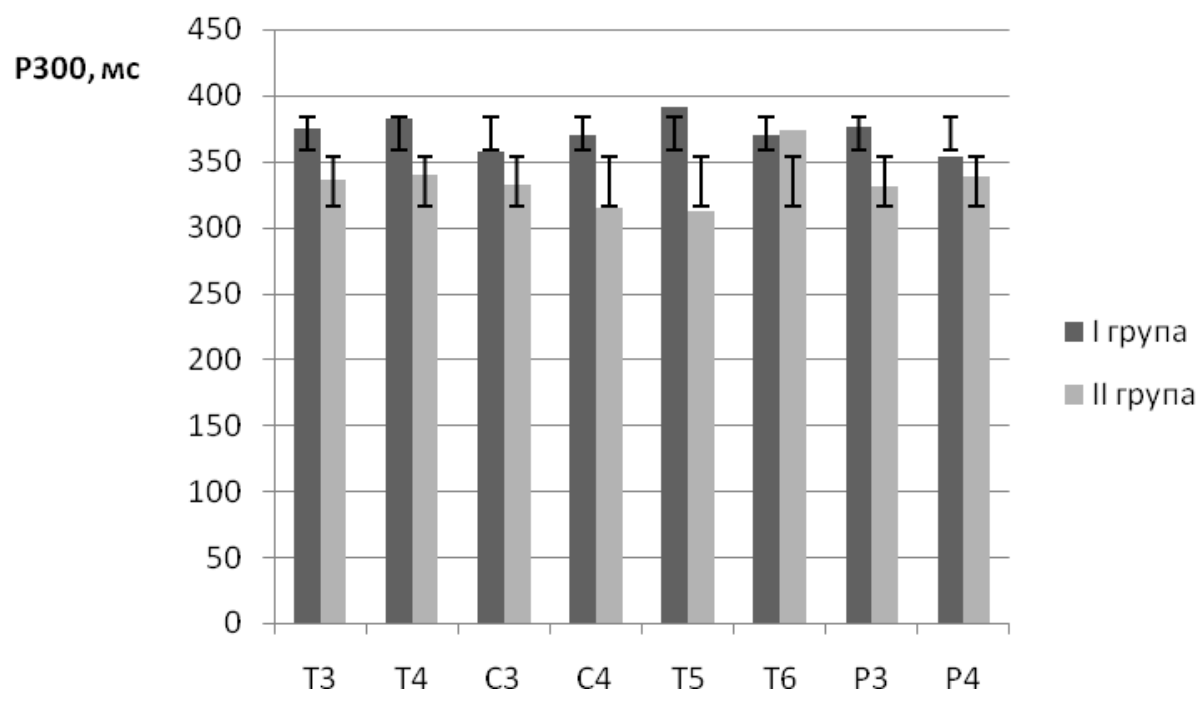

Рис. 2. Латентний період Р300 у спортсменів різних видів спорту в серії стимулів «Де»

Отримані результати є вагомим внеском у розвиток фундаментальних уявлень про механізми формування психофізіологічних, нейрофізіологічних та фізичних якостей у процесі спортивного тренування та вироблення критеріїв спортивного відбору.

Висновки та перспективи подальшого дослідження. Латентний період компоненти Р300 у спортсменів-легкоатлетів у серії стимулів «Що» відзначався статистично вищими значеннями у передньоскроневих та задньоскроневих відведеннях кори головного мозку. А в серії стимулів «Де» статистично вищими значеннями характеризувалися спортсмени ігрових видів спорту у тім'яних відведеннях. Спортсмени різних видів спорту мають свої особливості нервової системи, які проявляються у здатності опановувати складні рухові навички, швидкості реагування на відповідний сенсорний подразник та концентрації уваги.

Перспектива подальших досліджень полягає у вивченні амплітудно-часових характеристик позитивних та негативних компонент когнітивних викликаних потенціалів у спортсменів різних видів спорту.

\section{Джерела та література}

1. Гурова М. Б. Электрофизиологические характеристики внимания у спортсменов-тяжелоатлетов и единоборцев различной квалификации / М. Б. Гурова, Е. Ю. Дьякова, Т. А. Шилько // Вестник Томск. гос. ун-та. -2010 . - № 340. - С. 172-175.

2. Гурова М. Б. Особенности восприятия движений у спортсменов в зависимости от направленности тренировочного процесса / М. Б. Гурова, Л. В. Капилевич // Бюллетень сибирской медицины. - 2013. T. 12, № 2. - C. 195-199.

3. Капилевич Л. В. Взаимосвязь вызванных потенциалов головного мозга с уровнем специальной физической подготовленности футболистов / Л. В. Капилевич, Е. В. Замулина // Бюллетень сибирской медицины. - 2008. - № 2. - С. 112-114.

4. Кропотов Ю. Д. Количественная ЭЭГ, когнитивные вызванные потенциалы мозга человека и нейротерапия / Ю. Д. Кропотов ; пер. с анг. под ред. В. А. Пономарева. - Донецк : Изд. Заславский А. Ю. 2010. $-512 \mathrm{c}$.

5. Кривоногова Е. В. Когнитивный вызванныйпотенциал Р300 у молодых лиц при биоуправлении параметрами ритма сердца / Е. В. Кривоногова, Л. В. Поскотинова, Д. Б. Дёбин // Вариабельность сердечного ритма: Теоретические аспекты и практическо еприменение : Материалы $\mathrm{V}$ Всероссийского симпозиума с международным участием. - Ижевск, 2011. - С. 86-88.

6. Лизогуб В. С. Викликана активність мозку у людей з різними індивідуально-типологічними властивостями вищих відділів центральної нервової системи / В. С. Лизогуб, Л. І. Юхименко, С. М. Хоменко Ю. О. Дзюбан // Перспективи медицини та біології, 2012. - Т. IV, № 2. - С. 71-76. 
7. Муравський А. В. Показники когнітивних викликаних потенціалів (Р300) у боксерів 3 повторними легкими черепно-мозковими травмами / А. В. Муравський, Л. Л. Чеботарьова, О. С. Солонович // Зб. наук. праць співробіт. НМАПО імені П. Л. Шупика. - 2014. - № 23 (2). - С. 243-241.

8. Visual event-relatedpotentialsineliteandamateurathletes / Del Percio, Claudio, et al. // Brainresearchbulletin. 2007. - V. 74, № 1. - P. 104-112.

9. Skill-specific changes in somatosensory-evoked potentials and reaction times in baseball players / Koya Yamashiro, Daisuke Sato, Hideaki Onishi, Takuya Yoshida, Yoko Horiuchi, Sho Nakazawa, Atsuo Maruyama // Experimental Brain Research. - 2013. - V. 225, № 2. - P. 197-203.

10. Influence of Languageon Colour Perception: A Simulationist Explanation / Loïc P. Heurley, Audrey Milhau, Gabrielle Chesnoy- Servanin, Laurent P. Ferrier, Thibaut Brouillet, Denis Brouillet // Biolinguistics. - 2012. P. 354-382.

11. Hillyard S. A. Event-related brain potentials in the study of visual selective attention / Steven A. Hillyard, Lourdes Anllo-Vento // Processing of the Natoinal Academy of Sciences of USA. - V. 95, № 3. - P. 781-787.

12. Murakami T. Somatosensory evoked potentials and high-frequency oscillations in athletes / Takenobu Murakami, Kenji Sakuma and Kenji Nakashima // Clinical Neurophysiology. - 2008. - V. 119, № 12. - P. $2862-2869$.

13. Rauschecker B. T. Mechanisms and streams for processing of «What» and «Where» in auditory cortex / Josef P. Rauschecker and BiaoTian // Processing of the Natoinal Academy of Sciences of USA. - 2000. - V. 97, № 22. P. 11800-11806.

14. Characteristics of the athletes' brain: evidence from neurophysiology and neuroimaging / Nakata Hiroki, et al // Brain Research Reviews. - 2010. - V. 62, № 2. - P. 197-211.

Романюк Алена. Анализ компоненты Р300 у спортсменов игровых видов спорта и легкоатлетов (парадигма: «Что», «Где»). Спортсмены различных видов спорта обладают определенными особенностями нервной системы. Основой достижения высокого мастерства для спортсменов игровых видов спорта является умение концентрировать свое внимание, быстро реагировать на изменение игровой ситуации и принимать решения. Электрофизиологические методы исследования позволили определить роль различных структур головного мозга в процессах внимания и концентрации. Проведение информации к мозгу осуществляется двумя путями: вентральным, или «Что-системы» (включает вентролатеральную престриарную кору и нижневысочную кору) и дорзальным (включающим область теменной коры).

Выявлено статистически значимое различие латентности компоненты Р300 вызванных потенциалов мозга у спортсменов игровых видов спорта и легкоатлетов. У спортсменов игровых видов спорта отмечено статистически более длинный латентный период Р300 по сравнению с легкоатлетами при серии стимулов «Что». Отмечено обратную зависимость данных показателей между двумя группами обследуемых при появлении стимулов «Где».

Ключевые слова: вызванные потенциалы, компонента Р300, спортсмены, латентныйпериод.

Romaniuk Olena. Analysis Components of P300 Athletes Play Sports and Athletes (Paradigm: «What» «Where»). Athletes in various sports have certain peculiarities of the nervous system. The basis for achieving high skill for athletes sports game is the ability to focus quickly respond to changing game situations and make decisions. Electrophysiological methods possible to determine the role of different brain structures in the processes of attention and concentration. Carrying out the information to the brain in two ways: the ventral, or «What - system» and includes ventrolateralis prestriatum measles and measles and dorsal lower temporal, including parietal cortex region or «Where - system». Given the above said and the fact that the main component caused by the activity of the cerebral cortex (P300), which describes the analysis and decision making, today insufficiently studied and determine the relevance of our research. A statistically significant difference amplitude-time characteristics of the P300 component of the brain evoked potentials athletes play sports and athletes. In team sports athletes observed statistically higher latency period P300, compared to athletes during a series of incentives «What». Noted inverse relationship of these indicators between the two groups surveyed during an appearance in centives «Where».

Key words: evoked potentials, component P300, athletes, latencyperiod.

Стаття надійшла до редколегії 03.03.2015 p. 